\title{
GAMBARAN KASUS INCOMPATIBLE MAYOR PADA PERMINTAAN DARAH PACKED RED CELL (PRC) DI UNIT DONOR DARAH (UDD) PMI KOTA SURAKARTA PADA BULAN JANUARI - MARET TAHUN 2020
}

\begin{abstract}
An Overview of Major Incompatible Case Pack Red Cell on Demand for Blood Components at Blood Transfusion Unit City Indonesia Red Cross Surakarta at monthin January -March Two Thousand Twenty
\end{abstract}

\author{
Lia Fatmasari', Ni’mah Hidayatul Laili ${ }^{2}$ \\ Politeknik Akbara Surakarta \\ nimahhidayatullaili@gmail.com
}

\begin{abstract}
ABSTRAK
Latar Belakang :Pemeriksaan Crossmatching atau Uji cocok serasi adalah suatu rangkaian prosedur pemeriksaan mencocokan darah pasien dan darah donor dengan Jenis kelamin, Golongan darah, dan Hasil Crossmatch yang diperlukan sebelum darah diberikan kepada pasien, tujuan pemeriksaan ini untuk memastikan ada tidaknya aloantibodi pada darah pasien yang akan berinteraksi dengan darah donor bila di transfusikan.Pemeriksaan uji cocok serasi dapat dilakukan dengan metode tabung (metode konvensional) dan Gel Test.

Tujuan :Mengetahui Gambaran Kasus Incompatible Mayor pada permintaan darah Packed Red Cells (PRC) di UDD PMI Kota Surakarta.

Metode :Metode yang digunakan dalam penelitian ini adalah penelitian deskriptif kuantitatif dengan desain cross sectional dengan populasi 119 sampel dan sampel 119 sampel di UDD PMI Kota Surakarta pada bulan Januari - Maret 2020. Pengambilan sampel dengan teknik total sampling.

Hasil :Dari analisa univariat pada data sekunder didapat hasil data Incompatible Mayor pada permintaan komponen darah Packed Red Cell (PRC) sebanyak 119 pasien. Berdasarkan jenis kelamin , Laki - laki sebanyak 45 (38\%), perempuan $74(62 \%)$. Berdasarkan golongan darah terdapat golongan darah A Rh Positif 37 (34\%), B Rh Positif 33 (30\%), O Rh Positif 39 (35\%), AB Rh Positif 10 (1\%). Dengan hasil Crossmatch Mayor Positif Auto Kontrol (AK) Positif 93 (78\%), Mayor Positif Auto Kontrol (AK) Negatif 26 (22\%).

Kesimpulan :Terdapat gambaran hasil crossmatchincompatible mayor pada permintaan komponen darah Packed Red Cell(PRC) berdasarkan jenis kelamin mayoritas pada Perempuan sebanyak 74 (62\%), golongan darah O Rhesus Positif sebanyak 39 (3\%), dan hasil crossmatch Mayor Positif Auto Kontrol (AK) Positif sebanyak $93(78 \%)$.
\end{abstract}

Kata Kunci :Incompatible Mayor,Permintaan darah (PRC). 
Lia Fatmasari, Ni'mah Hidayatul Laili (Gambaran Kasus Incompatible Mayor Pada Permintaan Darah Packed Red Cell (PRC) Di Unit Donor Darah (UDD) PMI Kota Surakarta Pada Bulan Januari - Maret Tahun 2020)

\begin{abstract}
Background:Crossmatching examination or match-match test is a series of examination procedures to match the patient's blood and donor blood with the sex, blood type, and crossmatch results needed before blood is given to the patient, the purpose of this examination is to ensure that alloantibodies are present in the patient's blood that will interact with the patient. donor blood when transfused. Match test can be done by the tube method (conventional method) and the Gel Test.

Objective:The studi to knowing the Major Incompatible Case Analysis on perrequest for Packed Red Cells (PRC) blood at the Blood Donation Unit of the Indonesian Red Cross, Surakarta.

Methods:The method used in this research is quantitative descriptive research with cross sectional design with a population of 119 samples and a sample of 119 samples in the Blood Donation Unit of the Indonesian Red Cross in Surakarta City from January to March two thousand twenty. Sampling was taken using total sampling technique.

Results:From the univariate analysis on secondary data, the results of incompatible major data were obtained on the demand for packed red cell (PRC) blood components for 119 patients. Based on gender, as many as 45 male (38\%), 74 female (62\%). Based on the blood group, there are blood types A Rh Positive 37 (34\%), B Rh Positive 33 (30\%), O Rh Positive 39 (35\%), AB Rh Positive 10 (1\%). With the results of Major Positive Auto Control (AK) Positive 93 (78\%) Crossmatch, Major Positive Auto Control (AK) Negative 26 (22\%) results.

Conclusion:There are major incompatible crossmatch results on the demand for Packed Red Cell (PRC) blood components based on the majority sex female as many as 74 (62\%), blood type O Rhesus Positive as much as $39(3 \%)$, and the results of the Major Positive Auto Control (AK) crossmatch results. Positive as much as $93(78 \%)$.
\end{abstract}

\title{
Keywords:Incompatible Major, PRC blood demand.
}

\section{PENDAHULUAN}

Pemeriksaan Crossmatching atau Uji cocok serasi adalah suatu rangkaian prosedur pemeriksaan mencocokan darah pasien dan darah donor yang diperlukan sebelum darah diberikan kepada pasien, tujuan pemeriksaan ini untuk memastikan ada tidaknya aloantibodi pada darah pasien yang akan berinteraksi dengan darah donor bila di transfusikan (Permenkes, 2015). Pemeriksaan uji cocok serasi dapat dilakukan dengan metode tabung (metode konvensional) dan Gel Test. Metoda Gel Test selain lebih akurat juga lebih efisien waktu, hasil pemeriksaannya dilihat secara Makroskopis. Selain itu, metoda tube test juga memakan waktu yang lebih lama dibanding dengan metoda Gel Test. Perbedaan yang mencolok terletak pada pembacaan hasil, untuk metoda Tube Test mengunakan Makroskopis dan Mikroskopis sehingga memeperbesar resiko kesalahan petugas atau human error (Irawaty, 2016). 
Lia Fatmasari, Ni'mah Hidayatul Laili (Gambaran Kasus Incompatible Mayor Pada Permintaan Darah Packed Red Cell (PRC) Di Unit Donor Darah (UDD) PMI Kota Surakarta Pada Bulan Januari - Maret Tahun 2020)

Dalam melakukan pemeriksaan sering ditemukan adanya pemeriksaan crossmatching yang hasilnya incompatible. Incompatible hal yang menyebabkan aglutinasi pada darah pasien apabila dilakukan transfusi (Setyati, 2010). Sel darah merah (packed red cell/PRC) merupakan komponen darah yang paling sering ditransfusikan. Sel darah merah berfungsi mengalirkan oksigen dari jantung ke seluruh tubuh serta membuang karbon dioksida dan zat-zat sisa tubuh dan dapat dipakai dalam pengobatan anemia, ginjal, hati, serta infeksi dan kekurangan endokrin. PRC mengandung sejumlah besar leukosit dan trombosit tergantung metoda sentrifugasi (Permenkes, 2015).

Berdasarkan standar dari World Health Organization (WHO), jumlah kebutuhan darah minimal di Indonesia adalah 2\% dari jumlah penduduk atau 5,2 juta kantong darah per tahun. Laporan tahunan di Unit Transfusi Darah (UTD) pada tahun 2016, baru 4,2 juta kantong darah yang tersedia, itu artinya indonesia masih kekurangan pasokan darah.

Permintaan darah di Palang Merah Indonesia (PMI) Kota Semarang cukup tinggi. Tercatat permintaan darah melalui PMI Kota Semarang mencapai 10.00011.000 kantong tiap bulan. Tingginya permintaan darah di PMI Kota Semarang juga dikarenakan tingginya tingkat kesadaran masyarakat akan kesehatan saat ini. Banyaknya masyarakat yang berobat itu berdampak pada permintaan dari di PMI Kota Semarang. Dulu sebelum banyak yang menggunakan BPJS Kesehatan, permintaan darah di PMI Kota Semarang rata-rata hanya 5.000-6.000 per bulan. Sekarang bisa naik dua kali lipat, dari sekian banyaknya permintaan darah itu, paling banyak adalah permintaan darah golongan $\mathrm{O}$ dan A.

Sesuai laporan tahunan Unit Donor Darah (UDD PMI) Kota Surakarta tahun 2014 penggunaan komponen darah Packed Red Cells (PRC) adalah 43.798 (64.2\%) dari 68.211 seluruh permintaan darah transfusi di Unit Donor Darah (UDD) PMI Kota Surakarta (PMI,2014). Studi pendahuluan yang dilakukan dengan wawancara petugas di PMI kota Surakarta pada permintaan darah pada permintaan komponen darah Packed Red Cell (PRC) tiap bulannya lebih banyak di bandingkan dengan permintan komponen darah lainnya, banyaknya permintaan komponen darah Packed Red Cell (PRC) untuk kasus pasien anemia, thalasemi, dan Chronic Kidney Disease (CKD) atau gagal ginjal kronis (PMI Surakarta, 2020).

Berdasarkan latar belakang diatas, peneliti tertarik untuk melakukan penelitian terhadap "Gambaran kasus incompatible Mayor pada permintaan darah Packed Red Cells (PRC) di Unit Donor Darah (UDD) PMI Kota Surakarta pada bulan Januari - Maret Tahun 2020".

\section{METODE}

Metode yang digunakan dalam penelitian ini adalah penelitian deskriptif kuantitatif dengan desain cross sectional dengan menggunakan data sekunder, yang akan menggambarkan jumlah permintaan darah PRC dengan kasus incompatible Mayor di Unit Donor Darah (UDD) PMI Kota Surakarta tahun 2020. Data yang diperoleh dari hasil survey ini selanjutnya digambarkan berdasarkan tujuan yang ingin dicapai. 
Lia Fatmasari, Ni'mah Hidayatul Laili (Gambaran Kasus Incompatible Mayor Pada Permintaan Darah Packed Red Cell (PRC) Di Unit Donor Darah (UDD) PMI Kota Surakarta Pada Bulan Januari - Maret Tahun 2020)

Variabel dalam penelitian ini adalah variabel tunggal yaitu Kasus Incompatible Mayor pada Permintaan Darah Packed Red Cell (PRC) di Unit Donor Darah (UDD) PMI Kota Surakarta pada bulan Januari - Maret Tahun 2020 .

Populasi yang digunakan dalam penelitian ini adalah semua pasien berdasarkan formulir surat permintaan komponen darah PRC di Unit Donor Darah (UDD) PMI Kota Surakarta pada bulan Januari - Maret 2020 yaitu sebanyak 119 Sampel. Teknik pengambilan sampel dalam penelitian ini menggunakan teknik sampel jenuh atau sering disebut total sampling.

\section{HASIL DAN PEMBAHASAN}

\section{Hasil}

Berdasarkan penelitian yang telah dilakukan, maka hasil penelitian disajikan dalam bentuk penyajian data yang sesuai dengan hasil pengolahan data yang telah dilakukan sebelumnya. Penelitian ini terlaksana dengan 119 sampel yang dijadikan data dan dikelompokan berdasarkan kategori : Jenis Kelamin, Golongan Darah, dan Hasil Crossmatch pada kasus incompatible mayor pada permintaan darah PRC di Unit Donor Darah (UDD) PMI Kota Surakarta pada bulan Januari Maret tahun 2020, disajikan dalam bentuk tabel dibawah ini :

Dari hasil pengolahan data yang dilakukan terhadap 119 sampel kasus incompatible mayor pada permintaan darah Packed Red Cell (PRC) di Unit Donor Darah (UDD) PMI Kota Surakarta pada bulan Januari - Maret 2020 diperoleh presentasi jenis kelamin laki-laki dan perempuan sebagai berikut :

Tabel 1 Kategori Jenis Kelamin

\begin{tabular}{cccc}
\hline No & Jenis Kelamin & Jumlah & Presentase \\
\hline 1. & Laki - laki & 45 & $38 \%$ \\
2. & Perempuan & 74 & $62 \%$ \\
& Total & 119 & $100 \%$
\end{tabular}

( Sumber Data Sekunder : PMI Kota Surakarta, 2020)

Berdasarkan data pada tabel diatas didapatkan hasil perhitungan berdasarkan jenis kelamin. Disimpulkan dari jumlah kasus Incompatible Mayor pada permintaan komponen darah Packed Red Cell (PRC) terbanyak yaitu berjenis kelamin Perempuan sebanyak 74 (62\%) sampel.

Dari hasil pengolahan data yang dilakukan terhadap 119 sampel pada kasus incompatible mayor pada permintaan komponen darah Packed Red Cell (PRC) di Unit Donor Darah (UDD) PMI Kota Surakarta pada bulan Januari - Maret 2020 diperoleh presentasi golongan darah sebagai berikut : 
Avicenna : Journal of Health Research, Vol 4 No 1. Maret 2021 (15 - 23)

Lia Fatmasari, Ni'mah Hidayatul Laili (Gambaran Kasus Incompatible Mayor Pada Permintaan Darah Packed Red Cell (PRC) Di Unit Donor Darah (UDD) PMI Kota Surakarta Pada Bulan Januari - Maret Tahun 2020)

Tabel 2 Kategori Golongan Darah

\begin{tabular}{cccc}
\hline No. & Golongan Darah & Jumlah & Presentase \\
\hline 1. & A Rh Positif & 37 & $34 \%$ \\
2. & B Rh Positif & 33 & $30 \%$ \\
3 & O Rh Positif & 39 & $35 \%$ \\
4 & AB Rh Positif & 10 & $1 \%$ \\
& Total & 119 & $100 \%$ \\
\hline
\end{tabular}

(Sumber Data Sekunder :PMI Kota Surakarta, 2020)

Berdasarkan data pada tabel diatas didapatkan hasil perhitungan berdasarkan kategori golongan darah. Disimpulkan dari jumlah kasus Incompatible Mayor pada permintaan komponen darah Packed Red Cell (PRC) terbanyak yaitu bergolongan darah O Rh Positif sebanyak 39 (62\%) sampel.

Dari hasil pengolahan data yang dilakukan terhadap 119 sampel kasus incompatible mayor pada permintaan darah Packed Red Cell (PRC) di Unit Donor Darah (UDD) PMI Kota Surakarta pada bulan Januari - Maret 2020 diperoleh presentasi Hasil Crossmatch Incompatible Mayor sebagai berikut :

Tabel 3 Hasil Crossmatch Incompatible Mayor

\begin{tabular}{cccc}
\hline No. & Hasil Crossmatch & Jumlah & Presentasi \\
\hline 1. & Mayor Pos AK Pos & 93 & $78 \%$ \\
2. & Mayor Pos AK Neg & 26 & $22 \%$ \\
& Total & 119 & $100 \%$
\end{tabular}

(Sumber Data Sekunder :PMI Kota Surakarta, 2020)

Berdasarkan data pada tabel diatas didapatkan hasil perhitungan berdasarkan hasil crossmatch. Disimpulkan dari jumlah kasus Incompatible Mayor pada permintaan komponen darah Packed Red Cell (PRC) terbanyak yaitu hasil Mayor Pos AK Pos sebanyak 93 (78\%) sampel.

\section{Penyajian data tabulasi silang antara karakteristik dengan hasil Crossmatch}

Dari hasil pengolahan data yang dilakukan terhadap 119 sampel kasus incompatible mayorpada permintaan darah Packed Red Cell (PRC) di Unit Donor Darah (UDD) PMI Kota Surakarta pada bulan Januari - Maret 2020 diperoleh presentasi Hasil Crossmatch Incompatible Mayor sebagai berikut : 
Avicenna : Journal of Health Research, Vol 4 No 1. Maret 2021 (15 - 23)

Lia Fatmasari, Ni'mah Hidayatul Laili (Gambaran Kasus Incompatible Mayor Pada Permintaan Darah Packed Red Cell (PRC) Di Unit Donor Darah (UDD) PMI Kota Surakarta Pada Bulan Januari - Maret Tahun 2020)

Tabel 4 Tabulasi silang karakteristik dengan hasil Crossmatch

\begin{tabular}{|l|c|c|c|c|c|c|}
\hline $\begin{array}{r}\text { Crosmatch } \\
\text { Karakteristik }\end{array}$ & $\begin{array}{r}\text { Mayor Positif } \\
\text { AK Positif }\end{array}$ & \multicolumn{2}{c|}{$\begin{array}{c}\text { Mayor Positif } \\
\text { AK Negatif }\end{array}$} & \multicolumn{2}{|c|}{ Jumlah } \\
\hline Jenis Kelamin & F & $\%$ & F & $\%$ & F & $\%$ \\
\hline Laki-laki & 32 & 27 & 13 & 11 & 45 & 38 \\
\hline Perempuan & 61 & 51 & 13 & 11 & 74 & 62 \\
\hline Jumlah & 93 & 76 & 26 & 22 & 119 & 100 \\
\hline Golongan Darah & & & & & & \\
\hline A Rh Positif & 31 & 26 & 6 & 5 & 37 & 31 \\
\hline B Rh Positif & 26 & 22 & 7 & 6 & 33 & 28 \\
\hline O Rh Positif & 25 & 21 & 14 & 12 & 39 & 33 \\
\hline AB Rh Positif & 10 & 8 & 0 & 0 & 10 & 8 \\
\hline Jumlah & 92 & 77 & 27 & 23 & 119 & 100 \\
\hline
\end{tabular}

\section{Sumber Data Sekunder :PMI Kota Surakarta, 2020)}

Hasil Crossmatch berdasarkan karakteristik donor di dapatkan hasil tertinggi dengan Mayor Positif AK Positif 93 responden (76\%) terdiri dari , Jenis Kelamin Perempuan 61 Responden (51\%). Berdasarkan Golongan darah didapatkan paling banyak A Rhesus Positif sebanyak 31 responden (26\%). Hasil terendah dengan Mayor Positif AK Negatif sebanyak 26 responden (22\%), Jenis Kelamin Sama banding Laki-laki dan Perempuan sebanyak 13 responden (11\%), Golongan darah didapatkan paling banyak O Rhesus Positif 14 responden (12\%).

\section{Pembahasan}

Dari hasil penelitian diketahui bahwa 119 sampel kasus incompatible pada permintaan darah komponen darah Packed Red Cell (PRC) dengan hasil perempuan sebanyak 74 (62\%) sampel. Hasil penelitian ini sebagian besar kasus incompatible pada permintaan komponen darah Packed Red Cell(PRC) adalah perempuan dikarenakan perempuan lebih banyak mengalami resiko penyakit khususnya anemia (kelainanan jantung, gagal ginjal, artritis reomatoid, penyakit sumsum tulang). Dan perempuan lebih beresiko terkena pendarahan khususnya pada ibu melahirkan. Penelitian sejalan dengan penelitian Irawaty et altahun 2016. Disimpulkan bahwa jumlah jenis kelamin lebih banyak perempuan.

Berdasarkan perhitungan dari 119 sampel kasus incompatible mayor pada permintaan komponen darah Packed Red Cell (PRC) di Unit Donor Darah (UDD) PMI Kota Surakarta pada bulan Januari - Maret 2020 dengan jumlah terbanyak pada golongan darah O Rh Positif sebanyak 39 (35\%) sampel.Golongan darah merupakan ciri khusus darah dari suatu individu karena adanya perbedaan jenis karbohidrat serta protein pada permukaan membran sel darah merah (Oktavia, Murpi dan Indra, 2011). Dikarenakan mayoritas penduduk bergolongan darah O Rh Positif. Orang bergolongan darah $\mathrm{O}$ memiliki sel darah tanpa antigen, tapi memproduksi antibodi terhadap antigen A dan B. Sehingga orang dengan golongan darah $\mathrm{O}$ dapat mendonorkan darah kepada orang dengan golongan darah 
Lia Fatmasari, Ni'mah Hidayatul Laili (Gambaran Kasus Incompatible Mayor Pada Permintaan Darah Packed Red Cell (PRC) Di Unit Donor Darah (UDD) PMI Kota Surakarta Pada Bulan Januari - Maret Tahun 2020)

ABO Dan disebut donor universal. Namun orang dengan golongan darah $\mathrm{O}$ hanya dapat menerima darah dari sesama golongan darah O (Trishnanti D, 202017). Penelitian ini bertolak belakang dengan penelitian Teuku Ilhami et al tahun 2018 yang menyimpulkan bahwa golongan terbanyak adalah B Rh Positif.

Dari hasil penelitian pada 119 sampel pada kasus incompatible mayor pada permintaan komponen darah Packed Red Cell (PRC) di Unit Donor Darah (UDD) PMI Kota Surakarta pada bulan Januari - Maret 2020 di dapat hasil pemeriksaan crossmatch diantaranya Mayor Positif AK Positif sebanyak 93 (78\%) sampel. Uji Silang Serasi merupakan pemeriksaan utama yang dilakukan sebelum transfusi yang memeriksa kecocokan antara darah pasien dan donor sehingga darah yang diberikan cocok (Setyati, 2010). Arti dari incompatible adalah apabila ditemukan salah satu atau kedua macam pemeriksaan ( mayor,minor) dan reaksi antar donor pada uji cocok serasi positif. Bila ditemukan hasil uji cocok serasi incompatible, dilakukan tindakan lanjutan sesuai dengan permasalahan reaksi yang ditentukan (Irawaty, November 2016).Pada pemeriksaan Crossmatch terjadi aglutinasi di Mayor dan AK dikarenakan adanya irreguler antibodi pada serum pasien. Sehingga perlu dilakukan pemeriksaan lanjutan DCT pada sel darah donor. Pemeriksaan Direct Coombs Test (DCT) Hasil pemeriksaan DCT Positif lakukan pemeiksaan ulang golongan darah, minta sampel baru, dicocokan maksimal dengan 6 kantong darah donor segolongan dengan pasien. Jika hasil masih sama $\mathrm{Hb}$ pasien lebih dari $5 \mathrm{gr} / \mathrm{dl}$, pasien tidak disarankan transfusi. Hb pasien kurang dari $5 \mathrm{gr} / \mathrm{dl}$ darah diberikan dengan reaksi mayor lebih rendah dari Auto Kontrol (AK) Pasien.Penelitian ini bertolak belakang dengan penelitian Irawaty et al tahun 2016 yang menyimpulkan bahwa hasil crossmatch terbanyak adalah Minor.

Dari hasil penelitian pada 119 sampel pada kasus incompatible mayor pada permintaan komponen darah Packed Red Cell (PRC) di Unit Donor Darah (UDD) PMI Kota Surakarta pada bulan Januari - Maret 2020 di dapat hasil Tabulasi silang karateristik dengan hasil Crossmatch tertinggi padaMayor Positif Auto Kontrol Positif 93 responden (76\%) terdiri dari jenis kelamin perempuan 61 Responden $(51 \%)$. Berdasarkan Golongandarah didapatkan paling banyak A Rhesus Positif sebanyak 31 responden (26\%). Analisis crosstab (tabulasi silang) adalah suatu analisis hubungan antara dua atau lebih variabel, yang digambarkan melalui hubungan antar baris dan kolom variabel. Jenis data yang digunakan pada analisis crosstab adalah data nominal atau ordinal Kitamura (2010). Penelitian ini bertolak belakang dengan penelitian Irawaty et al tahun 2016 yang menyimpulkan bahwa hasil crossmatch terbanyak adalah Minor.

\section{SIMPULAN DAN SARAN}

\section{Simpulan}

Berdasarkan penelitian yang telah dilakukan peneliti dapat disimpulkan Pada Permintaan Komponen Darah Packed Red Cell (PRC) kategori Jenis kelamin, didapatkan hasil yang lebih dominan pada sampel yang berjenis kelamin Perempuan sebanyak 74 (62\%) sampel. Pada Permintaan Komponen Darah Packed Red Cell (PRC) kategori Golongan darah, didapat hasil yang lebih 
Lia Fatmasari, Ni'mah Hidayatul Laili (Gambaran Kasus Incompatible Mayor Pada Permintaan Darah Packed Red Cell (PRC) Di Unit Donor Darah (UDD) PMI Kota Surakarta Pada Bulan Januari - Maret Tahun 2020)

dominan pada sampel yang bergolongan darah O Rh Positif sebanyak 39 (35\%) sampel dan golongan darah yang paling sedikit yaitu golongan darah $\mathrm{AB} R \mathrm{R}$ Positif sebanyak 10 (1\%) sampel.

Pada Gambaran Kasus Crossmath pada permintaan Komponen Darah Packed Red Cell (PRC) pada hasil crossmatch didapatkan hasil yang lebih dominan pada hasil Mayor Positif Auto Kontrol (AK) Positif sebanyak 93 (78\%) sampel. Pada Gambaran Kasus Crossmath pada permintaan Komponen Darah Packed Red Cell (PRC) Hasil Tabulasi silang karateristik dengan hasil Crossmatch tertinggi pada Mayor Positif Auto Kontrol (AK) Positif 93 responden (76\%) terdiri dari jenis kelamin perempuan 61 Responden (51\%). Berdasarkan Golongan darah didapatkan paling banyak A Rhesus Positif sebanyak 31 responden (26\%).

\section{Saran}

Berdasarkan simpulan diatas dapat diajukan saran bahwa Karyawan hendaknya lebih berhati-hati dalam melakukan pemeriksaan uji cocok serasi khususnya jika mendapatkan kasus incompatible dan melakukan tindakan lanjutan dengan teliti. Diharapkan penelitian ini bisa mejadi bahan dalam pembelajaran di kalangan tenaga kesehtan dan untuk penelitian mendatang peniliti bisa lebih luas dalam penelitian yang berkaitan dengan kasus incompatible mayor pada permintaan komponen darah Packed Red Cell(PRC).

\section{DAFTAR PUSTAKA}

Astuti dan Laksono. 2013. Keamanan Darah di Indonesia. Surabaya: Health Advocacy.https://docplayer.info/437999-Keamanan-darah-di indonesia.html

Akbar, SIT, Ritchie, KN \& Sari, N 2019, Inkompatibilitas ABO pada neonatus di UTD PMI Kota Banda Aceh Tahun 2018.

Amiruddin, 2015, Apa yang Dimaksud Dengan Uji Silang Serasi darah Crossmatch pada Donor Darah, https:///www.dictio.id/t/apa-yangdimaksud-dengan-uji-silang-serasi-darah-crossmatch-pada-donordarah/13750

Anita, S, AM, R \& Arif, M 2015, Description of direct antiglobulin test in incompatibility.

Hidayat, A, 2012, Populasi dan Sampel: Pengertian Populasi Adalah?,https://www.statistikian.com/2012/10/pengertian-populasi-dansampel.html

Nency, Y. M., \& Sumanti, D. 2016. Latar Belakang Penyakit pada Penggunaan Transfusi Komponen Darah pada Anak. Sari Pediatri, 13(3). https://www.researchgate.net/publication/312407412_Latar_Belakang_Peny akit_pada_Penggunaan_Transfusi_Komponen_Darah_pada_Anak

Notoatmodjo, Soekidjo. 2012. Pendidikan dan perilaku kesehatan. Jakarta: Rineka Cipta.http://library.um.ac.id/free contents/index.php/buku/detail/pendidikan$\underline{\text { dan-perilaku-kesehatan-oleh-soekidjo-notoatmodjo-28714.html }}$ 
Avicenna : Journal of Health Research, Vol 4 No 1. Maret 2021 (15 - 23)

Lia Fatmasari, Ni'mah Hidayatul Laili (Gambaran Kasus Incompatible Mayor Pada Permintaan Darah Packed Red Cell (PRC) Di Unit Donor Darah (UDD) PMI Kota Surakarta Pada Bulan Januari - Maret Tahun 2020)

Permenkes, 2015. Peraturan Mentri Kesehatan No. 91 Tentang Standar Pelayanan Transfusi Darah.https://www.kemhan.go.id/itjen/2017/03/13/peraturanmenteri-kesehatan-republik-indonesia-nomor-91-tahun-2015-tentangstandar-pelayanan-transfusi-darah.html

Peraturan Menteri Kesehatan Republik Indonesia Nomor 83 Tahun 2014 Tentang Unit Transfusi Darah, Bank Darah Rumah Sakit, dan Jejaring Pelayanan Transfusi Darah. https://www.academia.edu/10444917/PERMENKES_No_83_Tahun_2014_ Tentang_UNIT_TRANSFUSI_DARAH_BANK_DARAH_RUMAH_SAKI T_DAN_JEJARING_PELAYANANTRANSFUSI_DARAH

Palang Merah Indonesia Semarang. 2020. Permintaan Darah Meningkat, diakses 5 April 2020, https://www.solopos.com/permintaan-darah-di-pmi-semarangtinggi-798700. 